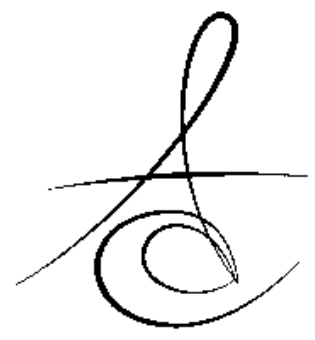

\title{
INFERIOR ALVEOLAR NERVE TRANSPOSITION IN CONJUNCTION WITH DENTAL IMPLANT PLACEMENT
}

\author{
INFERIOR ALVEOLAR SİNİR TRANSPOZİSYONU İLE BİRLİKTE \\ GERÇEKLEŞTİRİLEN DENTAL IMPLANT UYGULAMASI
}

\author{
Dr. Öğr. Üyesi Sercan KÜçÜKKURT ${ }^{*}$ Uzm. Dt. Tuğçe BİÇER AYTUĞAR ${ }^{* *}$
}

\begin{abstract}
Makale Kodu/Article code: 3153
Makale Gönderilme tarihi: 24.11.2016

Kabul Tarihi: 12.01 .2017
\end{abstract}

\section{ABSTRACT}

In the posterior mandible, dental implants are usually used to support fixed prostheses. In many cases, severe bone resorption occurs in this region following tooth extraction, and it is difficult to place implants in appropriate sizes due to the limitation of vertical distance of the inferior alveolar nerve (IAN). There are regenerative or reconstructive procedures in the posterior mandible to provide rehabilitation with implants in cases of excessive vertical bone loss. Repositioning of IAN is one of the alternative methods in the literature.

Full-mouth fixed mandibular prosthetic rehabilitation with dental implants was planned to a 62-year-old male patient in another clinic. However, in the left mandibular posterior region, placed implants were failed twice. In radiographic examinations, approximately $5 \mathrm{~mm}$ vertical height was determined in the posterior region. According to current clinical conditions, all available treatment options were discussed with the patient, and dental implant placement with nerve transposition technique was decided. Under local anesthesia, IAN was repositioned by implementing piezosurgery, and dental implants were placed successsfully. After one-year follow-up, there was no complaint or sensory loss.

At the right indications, IAN repositioning techniques are useful surgical procedures that can be used for the rehabilitation of the atrophic posterior mandible with dental implants.

Keywords: dental implant, nerve reposition, nerve transposition, nerve lateralization, inferior alveolar nerve

\section{öz}

Posterior mandibulada, dental implant uygulamaları genellikle sabit protezleri desteklemek amacıyla uygulanmaktadır. Ancak birçok vakada bölgede yaşanan diş kayıpları sonrasında oluşan ciddi rezorpsiyonlar nedeniyle özellikle inferior alveolar sinirin (IAS) vertikal boyut kısıtlamaları da eklenince uygun boyutlarda implant uygulamaları yapabilmek oldukça zor hale gelmektedir. Literatürde bu tip aşırı kemik rezorpsiyonu bulunan durumlarda dental implant uygulanabilmesine olanak sağlayacak çeşitli rejeneratif veya rekonstrüktif teknikler önerilmiştir. IAS'ın yeniden konumlandırıması teknikleri de literatürde geçen alternatif tekniklerden biridir.

62 yaşında erkek hastaya dış merkezde implant destekli tüm çene mandibular sabit protetik rehabilitasyon planlanmıştır. Ancak sol mandibula bölgeye yerleştirilen implantlar 2 defa tekrarlanmış ancak başarısız olmuştur. Tarafımızdan yapılan radyolojik muayenede bölgede $5 \mathrm{~mm}$ kemik yüksekliği tespit edilmiştir. Mevcut şartlar dahilinde hastaya uygulanabilecek tedavi alternatifleri açıklanmış ve nihayetinde sinir transpozisyon tekniği ile birlikte dental implant uygulanması kararlaştırımıştır. Lokal anestezi altında piezocerrahi yardımıyla sinir repozisyonu uygulanmış ve bölgeye implant uygulamaları başarıyla yapılmıştır. 1 yıllık takibin ardından hastada herhangi bir şikayet bulunmazken, duyusal bir kayıp tespit edilmemiştir.

Doğru endikasyonlarda sinir rezpozisyon teknikleri, atrofik posterior mandibular bölgelerin dental implantlarla rehabilitasyonuna olanak sağlayan kullanışlı tedavi seçenekleridir.

Anahtar Kelimeler: dental implant, sinir Repozisyonu, sinir transpozisyonu, sinir lateralizasyonu, inferior alveolar sinir

\footnotetext{
* Istanbul Aydın Üniversitesi, Diş Hekimliği Fakültesi, Ağız, Diş ve Çene Cerrahisi AD, İstanbul.

** İzmir Kâtip Çelebi Üniversitesi, Diş Hekimliği Fakültesi, Ağız, Diş ve Çene Cerrahisi AD, İzmir.
}

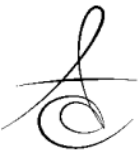




\section{INTRODUCTION}

Dental implants are often used to support fixed prostheses in the posterior mandible. In many cases, severe bone resorption occurs in this region following tooth extraction, and it is difficult to place implants in appropriate sizes due to the limitation of vertical distance of the inferior alveolar nerve (IAN). Therapeutic methods can be used in such cases including the use of short implants, the use of prosthetic cantilever bridges, and vertical bone grafting procedures to increase crest height. Another alternative method in the literature is shifting the IAN from the region with lateralization or transposition techniques ${ }^{1-6}$.

There are two different IAN repositioning techniques defined as lateralization and transposition. Nerve lateralization describes placing implants following exposure and laterally positioning of the IAN and relocating it over implants. In nerve lateralization, there is no interference with mental foramen or incisive branch of nerve. In nerve transposition, the bone is also removed from the mental foramen region and the incisive nerve branch is cut to ensure posterior repositioning of the mental foramen. $3,7,8$

It is known that transposition of IAN was first applied by Alling ${ }^{9}$ in 1977 . The first case of placing implants followed by IAN transposition was reported by Jensen and Nock $^{10}$ in 1987 . They modified this technique and applied by opening a canal from distal to the mental foramen, allowing the IAN to move on the cortical layer of the mandible using a large diameter round bur, and the researchers stated that this method could be used to placing implants in the atrophic crests. In 1992, Rosenquist ${ }^{11}$ placed 26 implants in 10 patients using IAN transposition and achieved successful results postoperatively. After this period, lateralization of the IAN was added as an alternative to the transposition technique. Nowadays, both methods are used ${ }^{12-15}$.

The purpose of this case report is to evaluate 1-year follow-up of the implants and IAN function in a patient who underwent IAN transposition procedure.

\section{CASE REPORT}

A 62-year-old male patient without any systemic disease applied to our clinic. According to his history, implant-supported fixed prosthetic treatment was planned for the treatment of mandibular total and maxillary partial edentulousness of the patient in another clinic. According to this plan, 12 dental implants, 7 in the mandible and 5 in the maxilla, were applied to the patient about 1 year ago. Short implants $(<8 \mathrm{~mm})$ are used in the posterior regions due to insufficient bone height. However, the implant on the left mandibular posterior region failed. (Fig. 1A) The patient stated that after repetitive implant placement and once again resulting with failure; finally, the patient had lost his confidence to his physician and applied to us. (Fig. 1B, 2)

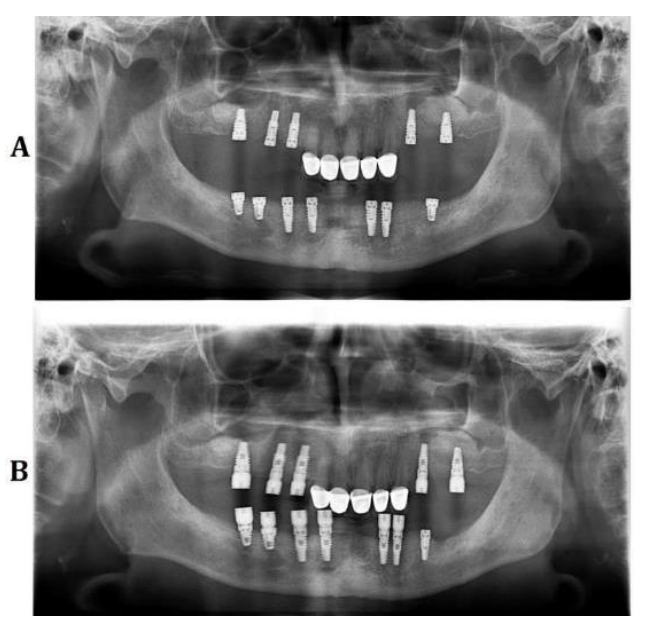

Figure 1. Previous orthopantomography images requested from another clinic A: First radiography B: Repetitive implant placed to mesial to the failed implant site

In clinical examination, mobility observed at the mentioned implant on the left mandibular posterior region. Also, on the left mandibular anterior region, bone and soft tissue loss were detected in the inter-implant region because the two implants were placed very close to each other. (Fig. 3) On the other hand, an implant was removed from the right maxillary premolar region after detecting that the implant was not osseointegrated. It has been decided to treat the upper jaw with the help of existing implants and to use the failed maxillary implant in the left mandible.

Radiographically, the area was examined using orthopantomography and $\mathrm{CBCT}$, and the distance between the alveolar crest and the IAN was determined to be $5-6 \mathrm{~mm}$ on average in the left mandibular posterior area. (Fig. 4) Also, the loop of the IAN after the mental foramen and accessory incisive nerve branch were determined. In the interviews with the patient, all alternative treatment 
options (repetitive re-treatment with extra short implants $(<6 \mathrm{~mm})$, bone augmentation methods, cantilever applications, etc.) were presented to the patient, and detailed information was provided. It has been decided that the nerve transposition procedure should be performed because of the patient's anticipation of success as soon as possible. The patient was informed in detail about the possible sensory changes due to nerve damage in the area after the procedure, and the informed consent forms were signed

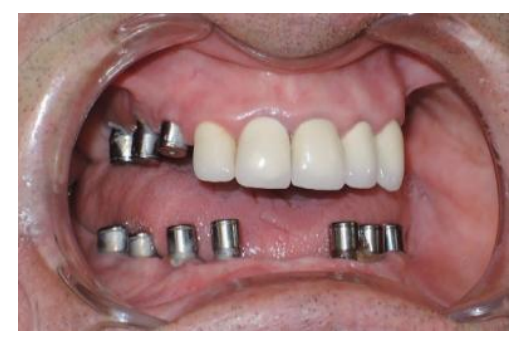

Figure 2. Preoperative intraoral image when the patient first applied to us

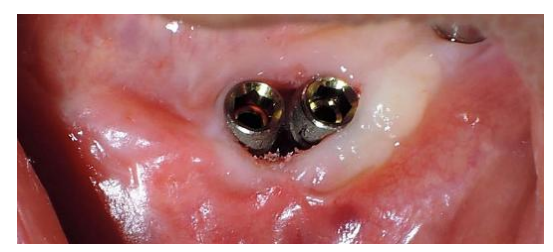

Figure 3. Bone and soft tissue loss in the inter-implant region because the two implants were placed very close to each other by breaking the dental implant placement rules.

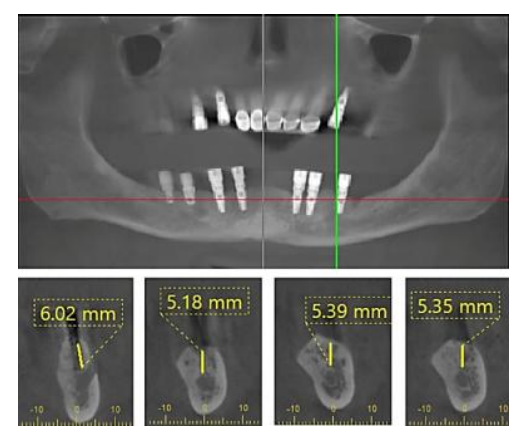

Figure 4. CBCT measurements of vertical bone height belong to left mandibular region

\section{SURGICAL PROCEDURE}

The operation date is set after 4 weeks to allow the soft tissue healing after removal of the implants from the region. During operation, loco-regional anesthesia of the IAN was achieved using $4 \%$ articaine hydrochloride containing 1:100.000 epinephrine. Following the crestal incision extending from the retromolar region to the lateral region, vertical releasing incisions were made. Then, the mucoperiosteal flap was raised, the mental foramen and neurovascular bundle were exposed carefully.

Using Woodpecker Ultrasurgery piezosurgery device (Guilin Woodpecker Medical Instrument Co., Ltd. Guangxi, P.R.C.), two different vertical osteotomy lines were obtained approximately $7 \mathrm{~mm}$ in length from the mesial and distal to mental foramen. The vertical osteotomy line on the mesial of the mental foramen was determined considering the nerve loop distance. The vertical osteotomy line located in the posterior was made in the second molar level, considering that the last implant would be placed in the first molar region and a new foramen would be created for the nerve outlet line. These vertical bone cuts were then combined with horizontal osteotomies. Care has been taken to include all osteotomy cuts made only in the outer cortical layer and partly in the trabecular bone. Approximately $5 \times 15 \mathrm{~mm}$ sized $3 \mathrm{~mm}$ thick bone window was removed from the mandible using a chisel. The bony window was placed in a sterile gauze sponge impregnated with saline during the procedure.

The IAN has shifted atraumaticly with the help of blunt tools used during sinus lifting, starting from mental foramen. In order to move the nerve from the mental foramen region, the nerve is interrupted with the anteriorly extending incisal branch. (Fig. 5)

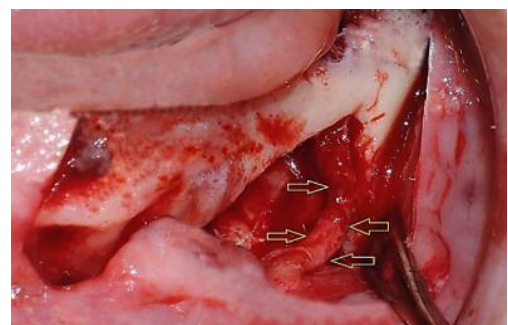

Figure 5. Exposed and shifted inferior alveolar nerve and newly formed foramen at second molar tooth level

IAN was protected with latex pieces prepared from a sterile glove, positioned laterally, and implant sites were prepared. In the first premolar and first molar regions 4.6-15 $\mathrm{mm}$, canine tooth region 3.8-12 $\mathrm{mm}$ and lateral tooth region $3.8-10 \mathrm{~mm}$ dental implants were placed. (BioHorizons IPH Inc., 
Riverchase Center Birmingham, AL, USA). In order to achieve primary stability with bicortical fixation, implant lengths have been applied as far as possible to the cortical layer on the basal plate, especially in the regions to which transposition has been applied. (Fig. 6A)

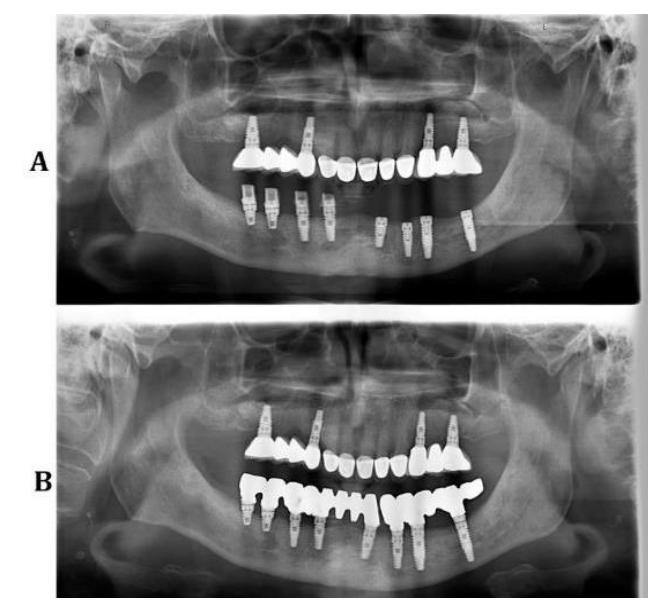

Figure 6. Postoperative orthopantomography images A: Operation day B: Four months later following prosthetic treatment (Between premolar and molar implants, the region where the canal was formerly, almost disappeared and new bone formation can be observed)

Trabecular bone particles obtained from the area mixed with xenograft (Apatos xenograft, Osteobiol by Tecnoss, TO, ITALY) and placed on the implant surface and then the cortical bone window was placed to the outer side. For the IAN, a new exit point with smooth edges was created with diamondtipped piezosurgery tips at the second molar tooth level. IAN was removed from this new foramen to outside, and the rest of the nerve was released between bone and soft tissue. The mucoperiosteal flap was sutured with a 4.0 silk suture. Sutures were taken on the tenth day after smooth healing. After the surgical procedure, oral antibiotics (Amoxicillin + Clavulanic Acid 1gr 2x1 / 7 Days), NSAID (Dexketoprofen 25 mg $2 \times 1$ / 7 Days), chlorhexidine gluconate (3x1/7 Days) were prescribed. In the postoperative period, possible paresthesia, hypostasis and hyperesthesia were informed in detail.

Basic tests (light touch, brush touch, two-point separation, and temperature change and pinprick tests) were performed to monitor sensory changes in the region on days 1,14 , and 30 and every 15 days until the implant phase. The post-op paresthesia and burning sensation in the area of the early period (first 30 days) gradually decreased, followed by post-op hypoglycemia in the 3rd month. This condition was interpreted as axonotomy according to the Seddon classification in the early period.

After a 12-week recovery period, gingiva formers of the implants were placed and, the patient was directed to the prosthetic department. Following the prosthetic treatment, it was observed that there was no complaint or sensory loss in the patient in the repeated tests following 1 year. Routine 6-month follow-ups continue. (Fig. 6B)

\section{DISCUSSION}

There are regenerative or reconstructive procedures in the posterior mandible to provide rehabilitation with implants in cases of excessive vertical bone loss. Some of those; vertical bone grafting methods, distraction osteogenesis, tilted placing of dental implants or short implant placement ${ }^{1}$, $2,5,6,16$. Autogenous vertical grafting methods often involve difficulty in closing soft tissue, exposure of the graft and rapid graft resorption, so more surgical sessions are needed and the duration of healing time is longer ${ }^{6,17}$. Distraction osteogenesis in the atrophic posterior mandibular is not always indicative of residual bone height deficiency and also needs expensive materials ${ }^{2,}{ }^{15}$. Placement of implants tangentially to the mesial, lingual or buccal side of the nerve, or the mesial side of the mental foramen is a complicated procedure, requiring extensive radiographic examinations and a higher risk of nerve injury ${ }^{4,11}$.

In the posterior mandible where implant placement is planned, decreasing vertical alveolar crest height between the crest and mandibular canal is the most important indication of IAN transposition/lateralization procedures ${ }^{10}, 13,18$. Vasconcelos Jde et al. ${ }^{19}$ has been reported that nerve repositioning is necessary when this height is between 5-8 mm. Fernandez et al. report that short implants cannot be used in $5 \mathrm{~mm}$ and below and that nerve repositioning is necessary in these cases. Lorean et al. ${ }^{14}$ reported a mean of $3,88 \pm 1,98 \mathrm{~mm}$ of vertical bone height above the IAN in patients with 79 cases of IAN transposition / lateralization.

Moreover, bicortical placement of the dental implant performed by this procedure affects the primary stability positively, which has a significant role 
in successful osseointegration ${ }^{12}$. As a biomechanical advantage, resistance to occlusal forces increases with the IAN repositioning and the relationship between implant and prosthesis improves ${ }^{20}$. It is administered under local anesthesia, provides low morbidity, stable outcomes, and additionally low cost. In addition, thanks to these techniques, unlike bone augmentation techniques, there is no need for donor sites that may disturb the patient in the post-op period. Also, the recovery period is shorter ${ }^{11}, 13,21$. Yoshimoto et al. ${ }^{22}$ reported that implant placement after nerve lateralization in the rabbit tibia showed bone apposition after two weeks and the healing period was completed in 8 weeks.

The disadvantages of this technique include the possibility of neurosensory dysfunctions that may occur after nerve manipulation. When mandibular nerve transposition or lateralization is applied, IAN damage, nerve compression or direct mechanical damage may occur as a result of mandibular canal deformation. Bleeding into the canal can lead to hematoma formation or compartment syndrome ${ }^{23}$. These sensory changes may manifest themselves as hypoesthesia (partial sensory loss) or paresthesia (abnormal response to stimuli) ${ }^{24}$. Nerve lesions may occur due to nerve compression during surgery or ischemia due to chronic compression after surgery ${ }^{25}$. Besides, this technique does not improve the anatomy of the alveolar cortex, temporarily weakens the mandible, and partly carries the risk of permanent sensory changes ${ }^{26}$.

Studies in the literature show that the success rate of implant placement following IAN transposition/ lateralization is high. However, it is possible that IAN will be damaged during bone removal or retraction. Some complications such as damage to the epineurium, laceration, crushing, rupture and infection and various neurosensory disorders due to this procedure can occur. However, in the post-IAN repositioning period, improvements in this dysfunction were reported between $80 \%$ and $100 \% .^{25,27}$ While the first improvement was reported between 3.8 and 5.7 weeks, complete healing could be prolonged from 6 months to 1 year $^{3,11,25}$.

Fernandez Diaz et al. ${ }^{28}$ evaluated 15 patients who undergone implant treatment followed by IAN lateralization, and that $95 \%$ of patients $(n=14)$ reported that IAN functions were normal at 8 weeks postoperatively. They reported a success rate of $97 \%$ in 38 implants. Khajehahmadi et al. ${ }^{8}$ investigated the sensory activity of the lower anterior segment before and after surgery. In the study, less frequent numbness in the lips and jaw areas after IAN lateralization reported. For this reason, they argued that there is less risk of paresthesia that can be seen in the lower frontal region in the lateralization process than in nerve transposition. Despite that in our case, there was no significant complaint in the patient in the long term, apart from the initial loss of sensation and burning sensation. Similar to our case, in a total of 87 patients, Hashemi ${ }^{29}$ evaluated 110 operating areas where the nerve was transposed before implant placement. He reported anesthesia in 81 patients, hypoesthesia in 9 patients, burning in 9 patients, pain in 8 patients, pain in 2 patients, and tingling in 1 patient during the first postoperative week. However, after a one-year follow-up, $94 \%$ of all patients reported that their complaints had disappeared entirely.

One of the most critical steps in IAN lateralization/transposition surgery is the osteotomy procedure in the buccal region. During this procedure, conventional rotary instruments or piezoelectric surgery can be used. In many studies in the literature, it has been argued that piezosurgery minimizes soft tissue injuries and osteotomies can be made more controlled, thus reducing the risk of nerve damage ${ }^{14,30,31}$. In our case, we also used a piezosurgery device to provide safer surgery and reduce the possibility of nerve damage.

Proussaefs $^{17}$ reported that placing the autogenous bone between the IAN and implant would also be useful in preventing future nerve sensitivity. In our case, the implant was positioned close to the lingual cortex, and the region was supported by xenograft, and trabecular bone particles scraped from the inner surface of the bone window. Thanks to piezosurgery, the removal of the bone as one piece and relocating it, did not necessitate the use of an extra barrier membrane in the region.

In the literature, the data on the amount of bone required between the canal and the alveolar crest is inadequate for application of IAN transposition. Jensen and Nock $^{10}$ noted that there should be a few millimeters of residual mandibular alveolar cortex over the upper osteotomy for a lateral window. Similarly, Rosenquist ${ }^{32}$ suggested that the lateral cortex of the canal should be removed as a block and that the coronal portion of the block should be a few $\mathrm{mm}$ below the alveolar cortex. Jensen et al. ${ }^{4}$ 
suggest that bone height should be $3-5 \mathrm{~mm}$ on the canal in order to apply IAN transposition. Autogenous bone grafting is recommended to achieve better results when the bone height on the mandibular canal is less. ${ }^{17,}, 32$

There are also several reports in the literature indicating mandibular fracture following implant placement to the atrophic posterior mandibula simultaneously with IAN repositioning. It is emphasized that during the application of the repositioning techniques, the removal of the buccal bone cortex leads to deterioration of structural integrity, and moreover, the placement of the implant in the region, makes the mandible vulnerable to stresses and may cause fractures ${ }^{18,33,34}$. In our case, during the healing period and 1-year follow-up, the fracture of the mandible did not occur.

\section{CONCLUSION}

As a result, IAN repositioning techniques are useful surgical procedures that can be used for the rehabilitation of the atrophic posterior mandible with the right indications. Also, these procedures can be performed with minimal risk, thanks to the use of modern methods such as piezosurgery. The risk of permanent damage to the nerve appears to be low if the technique is applied correctly and carefully. However, routine use of this technique requires prospective clinical trials and evaluation of patients in long-term follow-ups. Moreover, it should be considered that IAN repositioning techniques do not improve vast interarch distances which negatively affect crown-to-implant ratios.

Bu makale yazarlarından hiçbirinin makalede bahsi geçen konu veya malzemeyle ilgili herhangi bir ilişkisi, bağlantısı veya parasal çıkar durumu söz konusu değildir.

Serca Küçükkurt: ORCID ID: 0000-0002-4095-957X Tuğçe Biçer Aytuğar: ORCID ID: 0000-0002-0686-6476

\section{REFERENCES}

1. Jensen OT. Alveolar segmental "sandwich" osteotomies for posterior edentulous mandibular sites for dental implants. J Oral Maxillofac Surg 2006;64:471-5.

2. Rachmiel A, Emodi O, Aizenbud D. Reconstruction of the alveolar ridge by osteodistraction for implant placement. Refu'at ha-peh veha-shinayim 2011;28:30-6.
3. Morrison A, Chiarot M, Kirby $S$. Mental nerve function after inferior alveolar nerve transposition for placement of dental implants. J Can Dent Assoc. 2002;68:46-50.

4. Jensen J, Reiche-Fischel $O$, Sindet-Pedersen S. Nerve transposition and implant placement in the atrophic posterior mandibular alveolar ridge. J Oral Maxillofac Surg 1994;52:662-8

5. Felice P, Corinaldesi G, Lizio G, Piattelli A, Iezzi G, Marchetti C. Implant prosthetic rehabilitation of posterior mandible after tumor ablation with inferior alveolar nerve mobilization and inlay bone grafting: a case report. J Oral Maxillofac Surg 2009;67:1104-12.

6. Felice P, Iezzi G, Lizio G, Piattelli A, Marchetti C. Reconstruction of atrophied posterior mandible with inlay technique and mandibular ramus block graft for implant prosthetic rehabilitation. J Oral Maxillofac Surg 2009;67:372-80.

7. Smiler DG. Repositioning the inferior alveolar nerve for placement of endosseous implants: technical note. Int J Oral Maxillofac Implants 1993;8:145-50.

8. Khajehahmadi S, Rahpeyma A, Bidar M, Jafarzadeh $\mathrm{H}$. Vitality of intact teeth anterior to the mental foramen after inferior alveolar nerve repositioning: nerve transpositioning versus nerve lateralization. Int J Oral Maxillofac Surg 2013;42:1073-8.

9. Alling CC. Lateral repositioning of inferior alveolar neurovascular bundle. J Oral Surg 1977;35:419.

10. Jensen O, Nock D. Inferior alveolar nerve repositioning in conjunction with placement of osseointegrated implants: a case report. Oral Surg Oral Med Oral Pathol 1987;63:263-8.

11. Rosenquist B. Fixture placement posterior to the mental foramen with transpositioning of the inferior alveolar nerve. Int J Oral Maxillofac Implants 1992;7:45-50.

12. Suzuki D, Bassi AP, Lee HJ, Alcantara PR, de Sartori IM, Luvizuto ER, et al. Inferior alveolar nerve lateralization and implant placement in atrophic posterior mandible. J Craniofac Surg 2012;23:347-9.

13. Peleg M, Mazor Z, Chaushu G, Garg AK. Lateralization of the inferior alveolar nerve with simultaneous implant placement: a modified technique. Int $\mathrm{J}$ Oral Maxillofac Implants 2002;17:101-6.

14. Lorean A, Kablan F, Mazor Z, Mijiritsky E, Russe P, Barbu $\mathrm{H}$, et al. Inferior alveolar nerve transposition and reposition for dental implant placement in

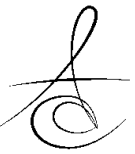


edentulous or partially edentulous mandibles: a multicenter retrospective study. Int J Oral Maxillofac Surg 2013;42:656-9.

15. Ferrigno N, Laureti $M$, Fanali S. Inferior alveolar nerve transposition in conjunction with implant placement. Int $\mathrm{J}$ Oral Maxillofac Implants 2005;20:610-20.

16. Tümer MK, Akbulut N, Yilmaz D, Erkmen E. Biomechanical Evaluation Of Effects Of Mandibular Monofocal Distraction Osteogenesis By Using Finite Element Analysis Method. J Dent Fac Atatürk Uni 2013; 21:350-5.

17. Proussaefs $P$. Vertical alveolar ridge augmentation prior to inferior alveolar nerve repositioning: a patient report. Int J Oral Maxillofac Implants 2005;20:296-301.

18. Luna AH, Passeri LA, de Moraes M, Moreira RW. Endosseous implant placement in conjunction with inferior alveolar nerve transposition: a report of an unusual complication and surgical management. Int J Oral Maxillofac Implants. 2008;23:133-6.

19. Vasconcelos Jde A, Avila GB, Ribeiro JC, Dias SC, Pereira $\mathrm{L}$. Inferior alveolar nerve transposition with involvement of the mental foramen for implant placement. Med Oral Patol Oral Cir Bucal 2008; 13:E722-5.

20. Sethi A. Inferior alveolar nerve repositioning in implant dentistry: a preliminary report. Int J Periodontics Restorative Dent 1995;15:474-81.

21. Dario LJ, English R, Jr. Achieving implant reconstruction through bilateral mandibular nerve repositioning. J Am Dent Assoc 1994;125:305-9.

22. Yoshimoto M, Konig BJ, Coelho PG, Allegrini SJ, Luiz FF. A light and scanning electron microscopy study of bone healing following inferior alveolar nerve lateralization: an experimental study in rabbits. Int J Oral Maxillofac Implant 2008;23:457-62.

23. Hirsch JM, Branemark PI. Fixture stability and nerve function after transposition and lateralization of the inferior alveolar nerve and fixture installation. Br J Oral Maxillofac Surg 1995;33:276-81.

24. Walter JM, Jr., Gregg JM. Analysis of postsurgical neurologic alteration in the trigeminal nerve. J Oral Surg 1979;37:410-4.

25. Nocini PF, De Santis D, Fracasso E, Zanette G. Clinical and electrophysiological assessment of inferior alveolar nerve function after lateral nerve transposition. Clin Oral Implants Res 1999;10:12030.
26. Babbush CA. Transpositioning and repositioning the inferior alveolar and mental nerves in conjunction with endosteal implant reconstruction. Periodontol 2000 1998; 17: 183-90.

27. Sandstedt P, Sorensen S. Neurosensory disturbances of the trigeminal nerve: a long-term follow-up of traumatic injuries. J Maxillofac Oral Surg 1995; 53:498-505.

28. Fernandez Diaz JO, Naval Gias L. Rehabilitation of edentulous posterior atrophic mandible: inferior alveolar nerve lateralization by piezotome and immediate implant placement. Int J Oral Maxillofac Surg 2013;42:521-6.

29. Hashemi HM. Neurosensory function following mandibular nerve lateralization for placement of implants. Int J Oral Maxillofac Surg 2010;39:452-6.

30. Sakkas N, Otten JE, Gutwald R, Schmelzeisen R. Transposition of the mental nerve by piezosurgery followed by postoperative neurosensory control: a case report. Br J Oral Maxillofac Surg 2008;46:2701.

31. de Castro e Silva LM, Pereira Filho VA, Vieira EH, Gabrielli MF. Tracheostomy-dependent child with temporomandibular ankylosis and severe micrognathia treated by piezosurgery and distraction osteogenesis: case report. $\mathrm{Br} \mathrm{J}$ Oral Maxillofac Surg 2011;49:47-9.

32. Rosenquist B. Implant Placement in Combination With Nerve Transpositioning: Experiences With the First 100 Cases. Int J Oral Maxillofac Implants 1994;9:522-31.

33. Karlis V, Bae RD, Glickman RS. Mandibular fracture as a complication of inferior alveolar nerve transposition and placement of endosseous implants: a case report. Implant Dent 2003; 12:211-6.

34. Kan JY, Lozada JL, Boyne PJ, Goodacre CJ, Rungcharassaeng $\mathrm{K}$. Mandibular fracture after endosseous implant placement in conjunction with inferior alveolar nerve transposition: a patient treatment report. Int J Oral Maxillofac Implants 1997;12:655-9.
Yazışma Adresi
Sercan KÜÇÜKKURT, Istanbul Aydın Üniversitesi Diş Hek. Fak.
Ağız, Diş ve Çene Cerrahisi AD, ISTANBUL - TÜRKİYE, e-mail: skucukkurt@gmail.com 